Cora, Y. T. (2022). Ermeni basınında 20. yüzyıl başında Çankırı ve Amasya panayırları. Uludağ Üniversitesi Fen-Edebiyat Fakültesi Sosyal Bilimler Dergisi, 23(42), 191-223.

DOI: $10.21550 /$ sosbilder.980913 Araştırma Makalesi / Research Article

\title{
ERMENİ BASININDA 20. YÜZYIL BAŞINDA ÇANKIRI VE AMASYA PANAYIRLARI
}

Yaşar Tolga CORA*

Gönderim Tarihi / Sending Date: 10 Ağustos / August 2021

Kabul Tarihi / Acceptance Date: 18 Ekim / October 2021

\section{ÖZET}

Yıllık panayırlar, Osmanlı coğrafyasında iktisadî ve sosyokültürel açılardan büyük öneme sahip ticarî organizasyonlardı. Panayırların 19. yüzyllın ikinci yarısından itibaren canlandiklarl ve hatta daha geniş bir coğrafyada kurulduklarl görülmektedir. Bu çalışmanın amacl, 20. yüzyllın başında Ermenice yayımlanan basında Çankırı ve Amasya panayırları hakkındaki yazıların incelenmesidir. Makalede İstanbul'da günlük çıkan Arevelk gazetesi ile ve aylı Bivrakn dergisinde yayınlanan, panayıra katılan tüccarın ve gözlemcilerin rapor ve haberleri kullanılmaktadır. Tüccar ve panayıra katılanların görüşlerinin incelenmesi, bu panayırların farklı ticarî yönlerine, satış usullerine, tacirler arası rekabete ve yöre halkı için sosyal fonksiyonlarına dair yeni bilgiler sunmaktadır. Panayırlara katılan tüccarın görüşleri üzerinden yapılan bir inceleme, panayırların kurulduğu şehirlerin ötesinde, geniş bölge ekonomisi üzerine olan etkilerini ve 20. yüzyılın başında Anadolu ekonomisindeki rollerini anlamamızı da sağlayacaktır.

Anahtar Kelimeler: Çankırı, Amasya, panayır, tekstil, iktisat politikaları

\section{Çankırı and Amasya Fairs in The Armenian Press in The Early Twentieth Century}

\begin{abstract}
Annual fairs were commercial organizations with great economic and social importance in the Ottoman world. Fairs began to revitalize and even new ones were
\end{abstract}

Dr. Öğr. Üyesi, Boğaziçi Üniversitesi Fen-Edebiyat Fakültesi Tarih Bölümü, İstanbul / TÜRKIYY, tolga.cora@ boun.edu.tr

Uludağ Üniversitesi Fen-Edebiyat Fakültesi Sosyal Bilimler Dergisi Uludağ University Faculty of Arts and Sciences Journal of Social Sciences

Cilt: 23 Sayı: 42 / Volume: 23 Issue: 42 
established in a wider geography from the second half of the nineteenth century onward. This article aims to examine the information on the fairs of Çankırt and Amasya in the Armenian language press in the beginning of the twentieth century. It uses the reports and news by the merchants and other participants in the fairs which were published in the daily Arevelk newspaper and monthly Bivrakn magazine of Istanbul. Observations by merchants and other participants provide us new information on issues like the commercial aspects of the fairs, sale methods, competition among the merchants and social functions of the fairs. This will also allow us to understand their impact on the broader regions beyond the fair sites and on the economy of Anatolia in the early twentieth century.

Key words: Çankırl, Amasya, fairs, textile, economic policies

\section{Giriş}

Osmanlı coğrafyasında yıllık panayırların iktisadî ve sosyokültürel yönlerinden ötürü toplumda önemli bir yer tuttukları bilinmektedir (Özcan, 2007: 206-208; Küpeli, 1999: 490-497). Panayırlar, farklı bölgelerde Türk Müslüman hâkimiyetinin başladığı dönemden ve hatta öncesinden itibaren kurulmaktaydılar (Özcan, 2006: 205-223; Şahin, 2013, 211-212). Bu tür panayırlar belirli bölgelerde, özellikle de Rumeli'de, Suriye'de ve İstanbul çevresinde kurulmuşlardır (Erdoğru, 1999: 3-5). Panayırların çoğu Anadolu ve Balkanlar Osmanlı idaresine geçtikten sonra da kurulmaya devam etmişler, bazıları zaman içerisinde işlevini yitirirken, aşağıda görüleceği üzere, mevcut panayırlara yenileri de eklenmiş ve hatta cumhuriyete intikal etmişlerdir (Çalışkan, 2019: 65-80; Doğan, 2011: 12-13). Rumeli'deki panayırların Anadolu'dakilerden daha kapsamlı oldukları kabul edilmektedir (Faroqhi, 2006: 157-186). Bununla beraber, bu makalenin konusu olduğu üzere başta Çankırı'da olmak üzere Orta Anadolu'da birçok önemli panayır kurulmuştur.

Yılın belirli bir döneminde kurulmaları, belirli bir süre boyunca devam etmeleri ve ticarî hacimleri ile haftalık pazarlardan ayrılan 
panayırlar, bölgesel ve hatta uluslararası nitelikte oldukları gibi farklı sosyal, kültürel ve dinî rolleri de olan organizasyonlardır. Panayırlar tacirleri, yerel dükkân sahiplerini ve halkı bir araya getirerek alışverişte bulunmalarını, dükkân sahiplerinin yıl boyu satacakları malları almalarını ve halkın da kendi kendilerine karşılayamadıkları ihtiyaçları edinmelerini sağlamışlardır. Merkezî idare, panayırları bir bölgenin refah seviyesini arttırması için ticareti geliştirmek, ulaşım imkânlarının eksikliğinden ötürü ihtiyacı karşılayamayan halkın mal teminine imkân vermek, köylünün malını satarak nakit gelir elde etmesiyle vergi ödemesini sağlamak gibi sebeplerle desteklemiş, sancak ya da kaza merkezi gibi idari değişikliklerin akabinde de panayırların kurulmasını sağlamıştır (Erdoğru, 1999: 12-13). Bu yüzden panayırlar, devlet müdahalesinin iktisadî kalkınma amacıyla yapıcı olarak kullanıldığ örnekler olarak karşımıza çıkarlar (Şen, 1996: 3-4). Panayırlar, iktisadî rolleri dışında halkın toplandığı sosyal alanlar olmalarından ötürü farklı fonksiyonlara da sahip olmuşlardır (Çalışkan, 2019: 72-73). Bu araştırmanın da ortaya koyduğu üzere Amasya panayırı örneğinde olduğu gibi bazı panayırların eğlenceler ile halkı alışveriş alanlarına çekmeye çalıştığı görülmektedir. Bazı panayırların da dinî törenlerle iç içe olduğu bilinmektedir (Şen, 1996: 10).

Merkezî idarenin panayırlar ile farklı yönlerden ilişkileri olmuştur. Merkezî idare, öncelikle yerel idareler ve eşraf ile birlikte panayırların organizasyonu kontrol ederek panayırların birbirini müteakip şekilde kurulmalarına ve böylelikle çakışmamalarına özen göstermiştir (Şen, 1996: 12; Küpeli, 1999: 492). Bunun yanı sıra, merkezî idare, panayırların kurulduğu alanlardaki imar faaliyetleri, özellikle de pazarın oluşacağı alanlardaki dükkân gibi ticarî alanlar ve panayırlara ulaşımın kolaylıkla sağlanması gibi konular üzerinde dikkatini yoğunlaştırmıştır (Şen, 1996: 20-21).

Devletin panayırlara ilgisinin bir sebebi de panayırlarda çeşitli vergilerin toplamasıdır. Bu vergiler arasında gümrük vergisi, satılan 
emtiadan alınan ve malın cinsine göre alınan bac vergileri, panayıra katılan gayrimüslimlerin panayırda bir arada olmasından ötürü toplanan cizye vergileri say1labilir (Küpeli, 1999: 493; Kaçan Erdoğan, 2016: 138147; Erdoğru, 1999: 14-15). Ayrıca merkezî idare panayırların kurulduğu alanlarda da vergi aldığı için panayır alanlarının mirî ya da vakıf arazisi olmasına göre bir gelir elde etmektedir (Erdoğru, 1999: 10-12). Son olarak, merkezî idarenin güvenliğinden sorumlu olduğu panayırlarda eşkıyalık ve şakiliğe karşı önlemler aldığı da bilinmektedir (Kaçan Erdoğan, 2016: 133-137).

Panayırlar üzerine yapılan çalışmalar (Şen, 1996; Küpeli, 1999; Erdoğru, 1999; Kaçan Erdoğan, 2016) büyük oranda arşiv vesikalarına dayandıklarından Süreyya Faroqhi'nin de belirttiği üzere bilgimiz panayırların merkezî idarenin gözünden nasıl göründüğü üzerinedir (Faroqhi, 2006: 159-160). Bu kaynaklardan bazıları, örneğin modern dönem öncesi bu vergilerin kaydedildiği varidat ve muhasebe defterleri gibi kaynaklar, tarihçilere panayırlardaki tacirler, satılan mallar ve geldikleri yöreler hakkında detaylı bilgi sağlamaktadır (Şen, 1996; Kaçan Erdoğan, 2016). Bu yüzden panayırları inceleyen çalışmalarda yukarıda saydığımız alanların ağırlıkla incelendiği söylenebilir.

Bununla beraber panayıra katılan tüccarın ve gözlemcilerin izlenimleri, panayırlara dair bilgimizi arttıracaktır. Özellikle de panayırlardan yazılan rapor ve mektuplar, imparatorluğun dâhili ticaretine dair yeni bilgiler verirken panayırların hem yerel ve bölgesel ticaretteki hem de sosyal hayattaki rollerine dair bir perspektif sunacaktır. Bu bakımdan 20. yüzyılın başında panayır bölgelerinden yazılmış, Ermenice yayımlanan basında çıkan rapor ve mektuplar, panayırların tarihi yazılırken kullanılmamış önemli kaynaklar olarak karşımıza çıkmaktadır. Bu makale 1900'lerin başında İstanbul'da yayınlanan Arevelk gazetesi ile ticarî haberler içeren Bivrakn dergisinde yayınlanan rapor ve mektuplar ışığında Çankırı-Yapraklı ve Amasya panayırlarına 
odaklanmaktadır. ${ }^{1}$ Bu panayırlarda gayrimüslim ve özellikle de Ermeni tacirlerin aktif oldukları bilinmektedir (Türkoğlu, 2008: 158). Bu çalışma, tacirlerin görüşleri üzerinden panayırlardaki ticarî ve iktisadî hayatı açıklarken, yerel halkın görüşlerine de yer vererek panayırların kuruldukları bölgelerdeki taşıdığı sosyal önemin altını çizmektedir.

\section{20. Yüzyılın Başında Orta Anadolu'da Panayırlar: Çankırı ve Amasya Panayırları}

Mevcut çalışmalarda ağırlıklı olarak Balkan ve Batı Anadolu kentlerinde kurulan panayırlar incelenmiştir. Bu yörelerin dışında Orta Anadolu ve Kızılırmak havzasında da birçok panayırın kurulduğu bilinmektedir. İskilip, Tosya, Amasya, Çerkeş, Merzifon, Çankırı (Karaca, 2017), Yapraklı (Türkoğlu, 2008), Zile (Girgeç, 2008), Yozgat (Özger, 2018) gibi şehirlerde bir dizi panayır kurulmuştur. Bu panayırların bir kısmı "kadimden beru" olmakla birlikte bir kısmı on dokuzuncu yüzyılın ikinci yarısında hatta yirminci yüzyılın başlarında kurulmuşlardır. Merkezî idarenin yürüttüğü iktisadi politikalar yeni panayırların kurulmalarının temel sebeplerinden biriydi. Bu iktisadi politikaların en önemlisi ise kuşkusuz 1860'lardan itibaren uygulanmaya başlayan vergi muafiyetleridir (Şen, 1996: 94-95).

Bununla beraber, merkezî idarenin yanı sıra yerel yöneticilerin de bölgelerinin iktisadî olarak kalkınması için bayındırlık faaliyetlerine ek olarak panayırlar kurmaya yöneldikleri görülmektedir. Amasya panayırına dair yerel halk bu yönde bilgi sunmuştur. 1906'da Amasya yöresinde yazılmış ve aşağıda daha detaylı ele alınacak olan bir rapor, "yarım asır önce çalışkan bir mutasarrıfın el atmasıyla bu panayır[ın] ilk kez gerçekleştiğini, sonra yılda bir kez, sonbaharda sadece üç günlüğüne" kurulduğunu söylemektedir (Bivrakn, 1906, 25 Kasım: 1045). Keza

\footnotetext{
${ }^{1}$ Osmanlı İmparatorluğu'nun iktisadi gelişimi, tarım, ticaret ve imalata dair haberler Arevelk gazetesinde önemli bir yer tutmaktaydı (Kostandyan, 2003: 8-16). 
bölgeden yazılan başka bir raporda da yine "40 yıl önce dönemin mutasarrıfı, yöreyi ekonomik olarak ilerletmek ve çevre ile ilişkileri arttırmak için panayır fikrine sahip oldu. İlk yıl gelen azdı, sonraki yıllar ise Ankara'dan, Sivas'tan, Trabzon'dan, Halep'ten, İran'dan kervanlar panayırın başlangıcından bir ay önce geliyorlardı, mahsus yerleri kiralıyorlar ve ticaret yapıyorlardı. Şimdi o kadar kalabalık yok. Bugün panayırımız sadece yerel." denilmektedir (Soğikyan, 1904: 1). Bu bilgiler panayırların tarihinin aslında oldukça dinamik olduğunu, farklı dönemlerde büyüyüp küçüldüklerini göstermeleri açısından önemlidir.

Orta Anadolu'da çeşitli sancak ve kazalar da 20. yüzyılın başında panayır kurma çabalarına girmişlerdir. Mesela, Çorum kazasının ileri gelenleri böyle bir talebi 1904 yılında merkezî idareye iletmişlerdir. Benzer bir örnek de 1907 yılında kurulan Kırşehir panayırıdır (Özger, 2018: 113). Bivrakn'a yansiyan bir habere göre Ankara Vilayet Meclisi "Kırşehir, Ankara, Yozgat, Kayseri, Nevşehir, Ürgüp, Aksaray ve Koçhisar'ın merkez noktasında belirli bir dönem bir panayır kurulmasının faydalı olacağını düşünerek, Yozgat panayırından sonra, Ağustos ortasına kadar, Kırşehir'in dışında, Ağzı Açık denilen yerde bir panayır gerçekleşmesine" karar vermiştir ve bu konuda bir irade-i seniyye alabilmiştir (Bivrakn, 1907, 3 Şubat: 277). Anadolu'da açılan bu gibi yeni panayırların İstanbul basınında haber olması hem bölgesel ticarî dinamizmi göstermesi hem de merkezî idarenin ticarî politikalarında panayırların yerini göstermesi açısından ilginçtir.

İlk bakışta Çankırı panayırı çok eski bir panayır izlenimi vermektedir. 1906 tarihinde başladığı kayıt altına alınmış olan Amasya panayırının aksine, yerel halk bu panayırın ne zaman başladığını bilmemektedir ve 1900'lerin başında bu panayırı kadim bir panayır olarak nitelendirmişlerdir (E., 1904: 1). Bununla beraber aslında Çankırı panayırı da göreceli olarak yenidir. 1906 yılında panayır hakkında bilgi veren bir yazara göre bu panayır, 15-17 yıl önce yani 1880'lerin sonu 1890'ların başında, Yapraklı denen dağda, panayır için inşa edilmiş 
ahşap dükkânlarda kurulmuş ve yaklaşık bir hafta süren bir panayırdır. Ticaretini tamamlayan tacirler şehre dönerek kalan mallarını orada satmak istemişlerdir. Sik sık yağan sağanak yağmurlar ve dükkân kiralarının artmasından ötürü şehirliler panayırı nizami dükkânların ve hanların olduğu şehre taşımışlar, böylece satıcılar da akşamları dinlenme imkânına sahip olmuşlardır. Yapraklı dağlarında panayır kurulmaya devam etmesine rağmen hayvan panayırına dönüşmüş ve ikincil öneme sahip olmuştur (Aşıkyan, 1906a: 822). Çankırı panayırı örneğinde görülen, panayırın şehrin çeperindeki bir alandan şehir merkezine taşınmasının başka örnekleri de vardır. Benzer bir şekilde Yozgat panayırı da önce şehrin yaklaşık 6 saat doğusunda bulunan Köhne'de kurulur iken daha sonra şehir merkezine taşınmıştır (Kapamacıyan, 1909: 195). Bu bilgilerden anlaşıldığı üzere panayırlar, Sultan İkinci Abdülhamid'in iktisadî politikalarının bir sonucu olarak kuruldukları bölgelerin, özellikle de şehirlerin piyasalarını canlandırmak amacıyla 19. yüzyılın son dönemlerinden itibaren şehirlere doğru taşınmaya başlamışlar, hayvan panayırları ise şehrin çeperlerinde kurulmaya devam etmişlerdir. $^{2}$

Panayırların tarihleri de her yıl değişiklik göstermektedir. Çankırı panayırı, 1904 yılında 15 Eylül tarihinde başlamış iken 1905'te 25 Eylül'e alınmıştır. Fakat bir yıl sonra tekrar eski tarihi olan 15 Eylül'e dönmüştür. Amasya panayırı ise 1904 yılında 15 Ekim'de ve 1905 yılında 7 Ekim'de başlamış iken 1906'da 10 Kasım'a ertelenmiştir (Bivrakn, 1906, 30 Eylül: 858). Panayırların tarihleri değişse bile birbiriyle çakışmamasına önem verildiği bilinmektedir. Bu sayede rekabetin önlendiği düşünülmektedir (Şen, 1996: 12). İncelediğimiz dönemde, 1906 yılında Niksar'ın Jermuk panayırı 15 Mayıs'ta, Yapraklı 8, Çankırı 13 ve Çerkeş 22 Eylül tarihlerinde kurulmaktadır. Tarih

\footnotetext{
${ }^{2}$ Sultan II. Abdülhamid döneminde yerel sanayinin geliştirilmesi ile iktisadî terakki fikrinin yakından ilişkili olduğu gösterilmiştir (Kilinçoglu, 2015: 85-126.).
} 
değişikliklerinin panayırların ticarî yaşamıyla doğrudan ilişkili olduğu görülmektedir. Birbirlerini takip eden panayırların, tacirler için rekabet yaratmaktan çok satılmayan mallarını satmaları için yeni pazarlar ve firsatlar olduğu gözlenmektedir. Ayrıca Çankırı panayırının bir ana panayır işlevi gördüğ̈̈ dolayısıyla da birbirini takip eden panayırlar arasında piyasa hacmi açısından bir hiyerarşi olduğu anlaşılmaktadır (Faroqhi, 2006: 168).

Yeni panayırlar kurulmasına rağmen panayırların imparatorluğun son döneminde önemini kaybettiklerine dair bir görüş de mevcuttur (Doğan, 2011: 11). 20. yüzyılın başında bu görüşün dönemde yaşayanlar arasında da yaygın olduğu görünmektedir. Mesela, 1904 yılında yazılan ve panayırların iktisadî önemini konu alan bir yazıda, panayırların gerek Avrupa'da gerekse Osmanlı İmparatorluğu'nda önemini kaybettiği belirtilmektedir (Arevelk, 1904, 28 Haziran: s. 1). Yazar, Fransa gibi geçmişte geniş katılımlı panayırların yapıldığı bir ülkede dahi artık sadece küçük ölçekli yerel panayırlar kurulduğunu belirtmektedir. Yazara göre panayırların faydaları, tüccar ile alıcıyı aynı yerde buluşturması ve zaman kaybını engellemeleridir. Bununla beraber ticaret ağlarının gelişmesi ile birlikte emtia panayırları azalarak sadece hayvan panayırları kalmaktadır (Arevelk, 1904, 28 Haziran: s. 1). Yazarın Avrupa'daki panayırlar için yaptığı bu gözlem, Osmanlı İmparatorluğundakiler için de doğrudur; hayvan satışının yapıldığ 1 panayırlar önemini korumaktadırlar. Gerek Yapraklı gerek ise Amasya panayırlarında hayvan satışı başlıca ticarî faaliyetlerdendir. Keza başka yörelerde de hayvan panayırları kurulmaktadır.

\section{Amasya Panayırı ve Hayvan Pazarı}

Amasya hayvan pazarı, şehrin yıllık et ihtiyacını karşıladığı gibi özellikle de Merzifon'daki deri imalathaneleri için de önemi haizdir. 1904 yılında Amasya'dan Arevelk gazetesine gönderilen bir mektupta panayır tasvirinin bir parçası olarak hayvan pazarındaki manzara 
anlatılmaktadır. Yazar, her yerde "hayr et/hayr ıne" sözleriyle havada düzenli biçimde sallanıp tokalaşan sağ ellerin olduğu bir manzarayı tasvir etmektedir. Yazara göre panayır sırasında Amasyalılar, zengin ya da fakir, bir inek, bir öküz ya da bir boğa alarak kış için et ihtiyaçlarını karşılamaktadır. $\mathrm{Bu}$ dönemde Kayserililerden öğrendikleri pastırma yapımının yaygın olduğunu da eklemektedir (Soğikyan, 1904: 1). Bir y1l sonra benzer şekilde yine Amasya panayırına dair bir mektup yazan ve Sofular Mahallesi sakini olan Keçeciyan da "bütün alanda aynı söz, "var hayır olsun" sözlerinin duyulduğunu yazarak Soğikyan'ın sözlerini teyit etmekte, hayvan pazarından alınan hayvanlarla şehrin büyük kısmının yıllık sucuk, pastırma, kıyma ve kavurma ihtiyacının karşılandığını söylemektedir (Keçeciyan, 1905: 1).

Amasya panayırına dair Bivrakn dergisindeki bir haber de hayvan panayırları ve önemi hakkında detaylı bilgiler vermektedir. Habere göre Amasya panayırı 10 Kasım 1906 tarihli cuma günü saat 5 civarında başlamıştır. Gelenek üzerine köylüler, Mutasarrıf Bey ve yerel yöneticiler mevcut olduğu hâlde şehirden 15 dakika uzaktaki meydanda, dağ eteğindeki açıklıkta, büyük bir kalabalıkla toplanmışlardır. Yazara göre bütün Amasyalılar hayvanlarını almak için ticarî hayatın biraz canlanacağı bu dönemi beklemektedirler; her ev, istisnasız bir öküz ya da inek almaktadır. Her evde, her çarşıda bir hareketlilik vardır. Sayısız atlar, öküzler, inekler, koyunlar panayır alanında hareket etmektedirler. Çevre köylerdeki köylüler de tarlalarda işlerini bitirmiş, iyi bir fiyata satmak için hayvanlarıyla panayıra gelmişlerdir. Panayırın bir iki günü kasaplar çok yoğundur, her bir kesimden 20-30 kuruş kazanmaktadırlar. En meşgul olan tacirler ise çok miktarda ucuza deri alan deri tacirleridir. Yazar çevre şehirlerden, Zile'den, Sim Hacı Köy'den, Köprü’den ve özellikle de Merzifon'dan panayıra epey deri tüccarının geldiğini 
söylemektedir. Öküz derisinin okkası 5.5-6 kuruştan satılmaktadır. ${ }^{3}$ Merzifonlu tacirler bazen aynı gün içinde, deri fiyatlarının düşeceğini bildiren bir telgraf aldıklarında satın aldıkları fiyatın üzerine koyarak derileri başkalarına satmaktadırlar. Tacirler arasında Merzifonlu Kalenderyan kardeşlerin Amasya Şubesi'nin temsilcisi Martiros Efendi Kalenderyan büyük miktarda deri alışı yapmıştır. Kalenderyan kardeşlerin Merzifon'da bir debbağhaneleri vardır, yerli seçilmiş ve dayanıklı deriler hazırlayıp İstanbul'a ve çevreye yollamaktadırlar. Benzer şekilde Amasyalı Sahakyan kardeşler de deri almışlardır. Bunlardan başka alım yapan bir grup Türk tüccar da vardır ve onlar arasında Merzifonlu Hacı Mustafa Ağa diğer tacirlerden daha büyük miktarda bir alım yapmıştır. Yazar yaklaşık hesapla 1200 adet öküz ve inek, 100 adet sığır, 50 tane at, 100 adet katır satıldığını yazmaktadır. Her bir sığırın derisinin yaklaşık 1.5 altın olduğunu ve 1905 yılındaki panayırla karşılaştırıldığında hayvanların ve diğer emtianın fiyatının artmış olduğunu belirtmiştir (Bivrakn, 1906, 25 Kasım: 1045).

$\mathrm{Bu}$ haberden Amasya panayırında satılan hayvanların sadece şehrin et ihtiyacını değil daha geniş bir bölgedeki üreticilerin deri ihtiyacını da karşıladığ 1 ve debbağlık zanaatının devamını sağladığı anlaşılmaktadır. Benzer bir şekilde Yozgat panayırının da Kayserili pastırma tacirlerinin et ihtiyaçlarını karşıladığı bilinmektedir (Kapamacıyan, 1909: 194). Bu bilgiler ışığında hayvan panayırlarının hayvan temelli üretim kolları için hammadde sağladıkları ve belirli bölgelerde bu alanların gelişmelerine dolaysız olarak katkıda bulundukları düşünülebilir.

\footnotetext{
${ }^{3}$ Bir okkanın ağırlığı şehirlere göre değişiklik gösterse de yaygın olarak 1282 gramdır. (Pakalın, 1993: 723).
} 


\section{3. Çankırı Panayırı}

Çankırı panayırının oldukça canlı bir emtia pazarı olduğunu panayıra katılan tüccarın ve yerel halkın gazetelere yolladıkları mektup ve yazılar ispat etmektedir. İstanbul'da Ermenice yayınlanan ve imparatorluğun ticaret hayatına dair bilgiler veren Bivrakn dergisinin 1906 yılının sonbahar aylarında çıkan sayılarında Çankırı panayırı üzerine bir dizi makale yayınlanır. Bunlar derginin Tokat temsilcisi Keork Aşıkyan'ın panayırın ve bölgenin ticarî hayatından izlenimlerini içerdiği gibi bu yazılara tüccarın verdiği cevapları kapsamaktadır.

Aşıkyan'a göre eskiden Çankırı-Yapraklı panayırına daha geniş bir coğrafyadan, Halep, Şam, Diyarbekir ve Mardin'den tüccar katılmaktaydı ve her tüccar grubunun kendi han ve pazarları vardı. 20. yüzyılın başında artık gelmiyor olsalar bile Haleplilerin hanı, Diyarbakırlıların pazarı şehirde hâlâ hatırlanmaktadır. Fakat son yıllarda bu şekilde uzun mesafeli ticaret yürüten tacirlerin sayısı azalmış, sadece çevre sancak ve vilayetlerden gelen alıcılar kalmıştır. Tokat'tan eski vakitte Çankırı panayırına bakır, yazma, bez, aba denen hazır kıyafetler, ipekliler ve kaytan tacirleri gelirken, bazılarının zanaatları kötüye giderek, Çankırı panayırına gitmeyi sonlandırmışlar ve sadece yazma, bez ve son zamanlarda kuşak tüccarı kalmıştır.

Aşıkyan da panayırların eski vaziyetlerini kaybettiklerine inanmaktadır. Yazara göre eskiden tüccar bir yıllık ihtiyaçlarını bir seferde alıyor ve bütün yıl o malı satmakla uğraşıyordu. Artık ticaret ve nakliye olanaklarının gelişmesiyle uzak yerlerden sipariş ve komisyonlar tüccara ulaşmaktaydı. Tacirler siparişlerini yazışmalar ile tamamlayabildikleri için bu şartlarda panayırların gerekliliği azalmaktaydı (Aşıyan, 1906: 822).

Panayırlar arasındaki ilişki çok önemlidir. Mevcut çalışmalarda merkezî idarenin panayırların birbiri ile çakışmaması için gösterdiği özene vurgu yapılmaktadır. Bunun yanında Aşıkyan'dan öğrendiğimize 
göre panayırlar piyasanın canlılığını gösterdikleri için canlı bir panayırdan sonraki panayırın da canlı geçeceği varsayılarak tüccar da bir sonraki panayıra dair hazırlıklarını ona göre yapmaktadır. 15 Mayıs 1906'da başlayan Jermuk panayırı çok iyi geçtiği için Tokatlı tüccar Çankırı panayırına da toptan mal getirmiştir (Bivrakn, 1906, 16 Eylül: 794). Fakat bu durum da aynı şekilde başarı bekleyenlerin sayısının da artmasıyla sonuçlanmıştır.

Panayırların üretim yapılan ve panayıra katılan şehirlerin de ekonomilerine çeşitli etkileri bulunmaktadır. Mesela Tokat'ta beyaz tabir edilen kumaşların fiyatı talebin çokluğundan dolayı artarken, çalışanların azlığından dolayı işçi günlükleri iki katına çıkmakta, panayır zamanı malların fiyatları da \% 5-6 arttığından, tüccar beklediği kâra ulaşamamaktaydı.

Aşıkyan'a göre Çankırı panayırı için mal hazırlığı nedeniyle Tokatlı tacirlerin durumu çok daralmış ve borçlar üst üste binmiştir. Alıcılardan gelen paralar, malların üretimine ve işçilerin ücretlerine gitmiştir. Birçok tüccarın ümidi, hazır malların bolluğunu görerek, istemeyerek de olsa panayırda temerküz ederek, burada yıllık işlerinin büyüklüğüne ulaşmaktır. Nakit para geleceği ümidiyle piyasadaki işlerini kapatıp, yeni kredi ile çalışmaya başlamışlardır. Sadece beyaz olarak adlandırılan kumaş, iplik ve boya tacirleri değil kadın ve erkek iş̧̧ilerin büyük kısmı da büyük bir dikkatle panayırın başarısına odaklanırlar çünkü yıllık gelirlerinin büyük kısmını panayır için satılan mallar ve siparişler oluşturacaktır. Başarısızlık hâlinde ise tüccar borçlarını bir şekilde kapatmak zorunda olduğu için düşük fiyatla mallarını satacaktır. Başkaları ise bir miktar bekleyip başka piyasalara yöneleceklerdi, ama burada bir belirsizlik içinde kârlarının yüzde kaçını kaybedeceklerini bilmeyeceklerdir. Aşıkyan'a göre tüccar birkaç ay için piyasaların durgun olduğunu, ellerindeki malın azalacağını ve alıcıların birkaç ay sonra tekrar sipariş vereceklerini düşünmektedir (Aşıkyan, 1906a: 824). $\mathrm{Bu}$ bilgiler, panayırların sadece kuruldukları şehrin değil panayıra mal 
getiren bölgelerin ekonomilerine, özellikle de imalat sektörleri üzerine olan etkisini göstermesi açısından önemlidir.

Başka bir deyişle panayırlar, geniş bir bölgenin ekonomisi için önemleri sebebiyle küçülseler dahi cazibelerini korumaya devam etmektedirler. Zira yüzlerce liralık mal birkaç hafta içinde satılmaktadır ve tüccara nakit sağlamaktadır, oysa sipariş ile bunların elden çıkması aylar sürmektedir ve daha zahmetlidir. Tüccar panayırda nakit satarak borcunu kapatmayı ve daha fazla kredi faizi ödememeyi planlamaktadır, ayrıca alıcıları bir arada ve doğrudan göreceği için de alıcıların zevkine ve piyasadaki arz talep değişikliklerine de vâkıf olacaklardır. Bunlar panayırların 20. yüzyılın başında ticarî önemlerini korumalarının başlıca sebepleridir.

\section{1. Çankırı Panayırında Ticarî Faaliyetler}

Tokat gibi diğer çevre illerden gelen tüccarın hazırlıkları, Jermuk panayırının bitmesinden hemen sonra yani Çankırı panayırı başlamadan 2-3 ay öncesinden başlamaktadır. Aşıkyan'ın yazısında sıraladığı bu hazırlıklar eylül ayı başında tamamlanmış, tüccar Tokat'tan ayın 6'sında yola çıkmıştır (Aşıkyan, 1906a: 826). Merzifonlu bir tüccar olan M.E.'nin 1904 Çankırı panayırına gidiş yolculuğuna dair anlattıkları bu konuda aydınlatıcıdır.

M.E.'ye göre Ağustos ayı geldiğinde, belki 30 şehir ve kasabadan gelen tüccar yerel mallarını naklederler ve daha önceden belirlenen bir vakitte Çankırı'ya varır. Merzifonlu tüccar da yerel mamulleri olan manusa kumaşlarını peşin parayla satmak amacıyla panayırdan birkaç hafta önce yola koyulur. Kervanı yöneten kervanbaşı belinde büyük deriden kemer, kafasında uzun bir fes ile tüccarla nakliye ücreti pazarlığ 1 yaptıktan sonra atlarına malları yükleyerek yola çıkar.

9 Eylül sabahı Merzifon'dan yola çıkan tacirler, şehirden yarım saat uzaklıkta bir yerde 8-10 araba arka arkaya siralanırlar. Tacirler arabalarda şarkı ve türkülerle yola devam ederlerken bir yandan da "nasıl 
ve ne kadarını satabilirim” diye düşünmektedirler. Kervan dört gün sonra Çankırı'ya varır. Yol yorgunluğu üzerine malları bir dükkâna koyan tüccar orada geceler, zira kalacak bir oda bulmak çok zordur. Tüccar, daha sonra bir dükkân ayarlayarak malları çeşitlerine göre dizer ve panayır hazırlıkları böylece tamamlanır (E., 1904: 1).

Eylül'ün 10 ile 12'si arası bütün tüccar Çankırı'ya varmıştır ve M.E.'nin de belirttiği gibi her şeyden önemlisi ilk iş olarak bir dükkân kiralamaktır. Her şehrin tüccarının kendi pazarını kurduğu yukarıda belirtilmişti. Panayıra katılan tüccarın geldikleri şehirlerin isimleriyle anılan bu pazarlarda tüccar ortak kararla dükkânları bölüşür. Kiraların yüksekliği yahut dükkânların boş olmaması bazen pazarların taşınmasına sebep olmaktadır. Örneğin Tokatlılara ayrılan çarşı panayıra katılan tüccarın sayısının çok olmasından ötürü yetmemiş ve kiralar da yüksek olduğu için tüccar daha önce kullandıkları hanlarına gitmişlerdir. Han sahibi de kazanacağı gelirden ötürü bu karardan memnun olmuştur. $\mathrm{Bu}$ han Tokatlıların pazarı olarak adlandırılır.

Kiraların da yıldan yıla değiştiği görülmektedir. Mesela 1906 yılında panayır yerindeki dükkân fiyatları önceki seneye göre daha ucuzdur, 2-2.5 altın yerine 40-90 kuruşa bir dükkân tutmak mümkün olmaktadır. Tokatlı tüccar gibi Kastamonu ve Gürünlü tüccar da pazar yerlerini değiştirmişlerdir. Aşıkyan'a göre böyle yer değiştirmeler toplu olarak yapıldığı için tüccara büyük bir zararı bulunmamaktadır (Aşıkyan, 1906b: 920-921).

1906 panayırı zayıf başlamıştır. Dükkânlar panayır için kararlaştırılan resmi açılış gününden önceki akşam açılmışlardır. Çankırılı dükkân sahipleri yiğitbaşının önderliğinde pazarları doldurmuştur. Adet üzerine sadece yiğitbaşının pazarlık yapması ve alım kararı vermesi uygundur, ondan sonra her bir dükkân sahibi ayrı pazarlık 
yapmadan alışveriş yapabilmektedir." 1906 yılı yiğgitbaşısı Aşıkyan’ın sözleriyle "dürüst ve sempatik bir karakteri olan" Çankırı dükkân sahiplerinden Mahmutzade Hacı Mehmet Efendidir (Aşıkyan, 1906b: 921).

Her yıl panayırın açılışından önceki gece yiğitbaşının yaptığı pazarlıklarla toptan alışveriş olmaktadır ve o akşamki alışverişler panayırın ilk birkaç günü için fikir vermektedir. 1906 yılında ise Jermuk panayırının yükselttiği ümitlerin aksine zayıf bir başlangıç olmuştur. Aşıkyan’a göre panayırın zayıflığının sebebi, genel bir nakit darlığı ve Çankırı tüccarı ile panayıra gelen tüccar arasındaki rekabettir. Ayrıca panayır 1905 yılında 25 Eylül tarihinde kurulduğu için köylülerin tarlalarda işleri bitmiştir, ihtiyaçlarını karşılamak için şehre gelecek ve alışveriş edecek paraları vardır (Aşıkyan, 1906b: 922). Köylüler, panayırdan özellikle de Kastamonu mallarını almayı tercih etmektedir. Çankırılı tüccar panayırı erken açtırma isteklerini kabul ettirmeyi başarmıştır. Böylelikle köylülerin daha sonra kendilerinden alışveriş etmek zorunda kalacaklarını ümit etmektedir. Panayırın zayıf başlamasının başka bir sebebi ise Çankırı'da 1906 yazında ticaretin az olması, dükkân sahiplerinin ellerinde nakdin olmaması ve alışveriş güçlerinin düşük olmasıdır. Çankırılı tüccar panayır sırasında almayacaklarından emin olarak sonradan ve düşük fiyatla mal alabileceklerini planlıyordu (Aşıkyan, 1906b: 923). İmparatorluğun genel mali durumunun da panayırın canlılığına direk etkisi vardı. Mesela Merzifonlu tacir M.E. 1904 yılındaki panayırın önceki yıllardan daha canlı geçtiğini ve arzın az, talebin çok olduğunu söylemektedir. İstanbul'da da aynı dönemde epey iyi miktarda ticaret olduğu haberinin

${ }^{4}$ Yiğitbaşının dükkân sahiplerinin temsilcisi olarak hareket etmesi ve tüccarla pazarlık yapması kadim bir kurum olan yiğitbaşılığın 20. yüzyılın başındaki konumunu göstermesi açısından ilginçtir. Ahilik teşkilatından gelen bir kurum olan yiğitbaşılık için bakınız: Şahin, 2013: 549-550. 
ulaşmasının panayırdaki alışverişe olumlu katkıda bulunduğunu eklemiştir (E., 1904: 1).

\subsection{Tacirler Arasındaki Rekabet}

Yerel tüccar ile panayır tüccarı arasındaki rekabet kadar panayıra farklı yerlerden gelen tacirler arasında da rekabet bulunmaktaydı. Buna 1906 yılında Bivrakn'ın sayfalarına yansıyan Zile ve Merzifon tüccarı arasındaki rekabet örnek olarak verilebilir.

Panayırın başlangıcındaki durgunluk birkaç gün daha sürmüştü. Aşıkyan'a göre özellikle Merzifonlu tüccarın çarşısı bundan etkilenmişti. Merzifonlu tüccar kâr oranlarını korumak amacıyla aralarında anlaşarak alacanın fiyatını 7.5 kuruştan aşağı vermemeye karar vermişti. Bu da yerel dükkân sahipleri arasında bir tepki doğurmuş ve onlar da Merzifonlu tüccardan mal almamaya karar vermişlerdi. Merzifonlu tüccar fiyat kırmadığı için malları ellerinde kalmıştı. Zileli tüccar ise bundan faydalanmak amacıyla yiğitbaşına giderek Merzifonlulardan daha uygun fiyata mal vereceklerini söylemişti. Çankırılı dükkân sahipleri de bunu uygun bulmuşlar ve Zilelilerin malları bir gecede bitmişti.

Aşıkyan'ın belirttiğine göre geçmiş yıllarda Zilelilerin alacalarının satışı panayırda sona kalır ve böyle fiyatlarla satılmazken bu sene Merzifonlu tüccarın yüksek fiyatlarından ötürü erken ve iyi fiyata satılmıştı. Bunun üzerine de Merzifonlu tüccar da tek başlarına hareket etmeye ve mallarını 6.5 kuruşa kadar düşürerek satmaya başlamıştı. Böylece hem fiyatları düşürmüşler hem de nakit yerine vadeli satış yapmak zorunda kalmışlardı. Aşıkyan, Merzifonlu tüccarın malının daha iyi olmasından ötürü daha sabırlı oldukları takdirde istedikleri fiyata satabileceklerini iddia etmektedir. Çünkü iyi mallar dükkân sahipleri için yıl boyunca bir satış imkânı sunmaktadır.

Merzifonlu tüccar, Aşıkyan'ın eleştirilerine yine Bivrakn'da cevap verirler. Merzifon'un tanınmış tüccarından Deark Bedros 
Şahbenderyan, Hovsep Dudyan, Aram Çizmeciyan, M. Haçadur Daldapanyan, Misak Elbekyan ve Hovannes Keçeciyan, Çankırı panayırındaki Merzifon mallarıyla ilgili olarak dergiye ayrı ayrı mektuplar yazmışlar ve derginin Misak Elbekyan Efendi'nin gözlemlerini yayınlamasını talep etmişlerdi. Elbekyan Efendi'nin Aşıkyan'ın yazısına dair maddeler hâlinde sıraladığı eleştirileri ve düzeltmeleri şu yöndedir:

1. Merzifon'un tüm malları 650 balya olup, bunlardan 300 balyas 1 iyi fiyata peşin, 300 balyası da ortalama fiyata vade ile satılırken 50 balyası da düşük fiyata satılmışlardır.

2. Merzifonlu tüccarın zararı ileri görüş eksikliğinden değil panayırın genel olarak zayıflı̆̆ından kaynaklanmıştır. Malların fiyatlarını yükseltmek için şehirli tüccardan sipariş gelmemiştir.

3. Bu zarardan en az şekilde etkilenmek için Merzifon tüccarı mallarını 9 gün boyunca sabit fiyattan satmıştır. Sadece son 2 gün daha düşük fiyatla vadeli satarlarken son gün az miktarda, noksan fiyatla ve bağımsız olarak satmıştır.

Merzifonlu tüccar hiçbir zaman Zilelilerin sattıkları düşük fiyatlar karşısında fiyat indirmemiştir. Zileli tüccarın mallarını panayırın bitiminden 4-5 gün öncesinde düşük fiyatla ve vade ile satmaları Merzifonlu tacirlerinin Zileli tüccara göre fiyat kırmadığını göstermektedir. Eğer Zileli tüccara göre hareket etselerdi Merzifonlu tüccar da son günü beklemeden fiyat kırardı.

4. Merzifonlu tüccar "başkaları gibi malı sağda solda gezdireceklerine" 31, 61 ve 91 gün vade ile satmıştır çünkü "Merzifon manusa fabrikası gibidir, sipariş geldiğinde hızlıca üretir."

5. Panayırlarda alıcı ile satıcılar arasında birçok problem görülmesine rağmen birbirlerine dair saygılarında bir bozulma, hile, başka malı aynı fiyata satma gibi bir şey görülmemiştir. 
6. Merzifon mallarının fiyatları Zilelilere yardımcı olmamıştır. Zileliler panayırın ilk günlerinde Merzifon mallarının yüksek fiyatlarından faydalanarak çok küçük farkla bütün mallarını peşin fiyatına satıp stoklarını bitirebilirlerdi. Fakat mallarını bitirmek için son günlerinde \% 7-8 indirim ve vadeli satış yapmak zorunda kalmışlardır (Bivrakn, 1906, 25 Kasım: 1039-1041).

Aşıkyan ise Elbekyan'ın bu eleştirilerine, yayınladığı raporlardaki bilgileri Çankırılı dükkân sahiplerinden aldığını ve Merzifonlu tüccarın kendisine bilgi vermediğini belirterek cevap vermiştir. Kendisinin bir ayrım gözetmediğini, tek amacının imparatorluktaki imalat ve ticaretin arttırılması olduğunu eklemiştir (Aş1kyan, 1906d: 1192).

Diğer raporların ve Elbekyan ile Aşıkyan'ın karşılıklı mektuplarının gösterdiği üzere bir yörenin tüccarı, panayıra seyahat, beraber dükkân kiralama ve malların fiyat ve satış şekillerini (peşin veya vadeli) belirlemede büyük oranda birlikte hareket etmekteydi. Ancak panayırın sonunda mallarını ucuza ya da vadeyle satarak bitirmek ile başka bir panayıra götürmek konusunda kararı kendileri veriyorlardı. Bunun sebebi de belirli bir yörede üretilen malların kalitesinin ve müşteriyi cezbeden desen gibi unsurlarının büyük oranda birbirine yakın olması dolayısıyla satış konusunda büyük farklar oluşturmamalarıydı. Bu yüzden rekabet farklı şehirlerin tüccarı arasında yaşanıyordu.

\subsection{Panayırda Alıcılar}

Panayırın ilk başındaki durgunluk bir süre sonra çevre şehirlerden gelen tüccarın toptan alım siparişleriyle canlanır. Siparişler arasında en önemlileri Safranbolulu 12-14 tüccardan gelenlerdir. Bu tüccar, Tokat, Merzifon, Halep, Zile, Gürün ve diğer yerlerin ipek mallarına vadeli sipariş vermişlerdir. Kastamonu'dan gelen birkaç tüccar, İbranosyan kardeşler, Karabacakyan ve başka tacirler, Çerkeş panayırında satmak ve kalanını Kastamonu'ya götürmek için Tokat mallarına özellikle de 
yazmaya rağbet ederler. Bu da Çankırı panayırından sonra gerçekleşen Çerkeş panayırında satılan malların da bir kısmının Çankırı'dan alındığını ya da Kastamonu’ya dönen tüccarın malının bir kısmını yol üzerinde satmak için aldığını göstermektedir. Bu ayrıca panayırlar arasındaki hiyerarşiye de işaret eder. Mal almak için bölge dişından da tüccarın Çankırı panayırına geldiğini biliyoruz. Bunlar arasında İstanbul'dan Gizizzade Efendi 'âdeti olduğu üzere Tokat ve Merzifon mallarından büyük miktar almıştı" (Aşıkyan, 1906b: 924). Tosya, Çerkeş, Koçhisar ve Karaca Viran'dan gelen dükkân sahipleri de Tokat, Merzifon, Kastamonu ve Halep mallarını toplu alarak panayırın canlanmasına katkıda bulunmuşlardır. Ankara'dan da bir grup tüccar gelerek Tokat kuşağı ve bezi ve Kastamonu malı almıştır. Bartın'dan da Deark Tovmasyan ve Stambulyan da Tokat ve Kayseri ve diğer mallardan epey alım yapmışlardı (Aşıkyan, 1906b: 924-925). Bu örnekler Çankırı panayırının geniş bir coğrafyaya hizmet ettiğini göstermektedir.

Çevre şehirlerden gelen ve toptan mal alan tüccar ve dükkâncılardan sonra Çankırılı dükkân sahipleri de alışveriş yaparak canlılığa katkıda bulunmuştur. Bu şekilde 17 Eylül'e kadar ortalama fiyatlarla malların genel kısmı satılmıştır. Panayırın resmi olarak kapanmasına kadar olan 3 günde de epey satış gerçekleşmiştir. Yine de tüccar panayırın zayıflığından ötürü rahatsızlık duymaktadır çünkü mallarının ancak yarısını satmış durumdadır. Son üç gün fiyat kırarak bir kısım mal daha satılır fakat alıcıların da dönmeleriyle durgunluk tekrar başlar. Çankırılı dükkân sahipleri de nakit açısından darda oldukları için panayır tüccarı fiyat kırmak yerine vadeli satışa başlamıştır. Bu yolla dükkân sahipleri 61 gün vade ile Tokat kuşakları ve bezleri, Merzifon ve Halep malları, Gürün kuşakları, bir parça da Kastamonu malları almışlardır. Bundan sonra da malların yaklaşık 1/6'sı başka pazarlarda satılmak için kalmıştır (Aş1kyan, 1906b: 925). 
Aşıkyan, panayırdaki sayış fiyatlarının malların geldiği şehirlerindeki fiyatlardan \% 7-10 daha aşağıya olduğunu, bunun da ciddi bir kâr anlamına gelmediğini iddia eder. Aşıkyan ciro tahmini yapmadığ 1 için 1906 yılındaki panayırdaki ekonomik faaliyeti, 1904 yıllında M.E.'nin iddia ettiği gibi yıllık ortalama hesapla 60 bin altınlık faaliyetle (ki 1904 yılında fazlası olduğunu da ekler) karşılaş̧tırma imkânı yoktur (E., 1904: 1; Aşıkyan, 1906b: 1926). Yalnızca M.E. 1904 yılında her şeyin nakit satıldığını söylerken 1906 yılında ciddi miktarda vadeli satışların olduğu görülmektedir. Bu bilgiler yıllara göre panayırların hacminin ve emtia fiyatlarının değişikliklere açık olduğunu göstermektedir.

Aşıkyan, 1906 yılı panayırının zayıflığı konusunda tacirleri de eleştirir. Yazar "panayırdan ümit edilen başarılara ve her yıl tacirlerin çoğunun katılıp büyük kazançlar elde etmelerinin hayalini kurmalarına karşı, tacirler getirdikleri malların çeşidinin alıcıların zevklerine uygun olması gerektiği üzerine düşünmüyorlar. Dost alıcıları olmalı ve buralarda tanınır olmalılar ki mallarına talep olsun. Bu noktaları göz önüne alsınlar" demektedir (Aşıkyan, 1906b: 1926). Bu da panayırların başarısının genel iktisadî şartlar kadar tüccarın satış ilişkileri ve alıcılarla olan münasebetleri gibi birçok farklı etkene bağlı olduğunu göstermektedir.

\section{4. Çankırı Panayırına Katılan Tüccar ve Malları}

Aşıkyan, 1906 yılında Çankırı panayırına katılan tüccar, geldikleri şehirler, mallarının çeşit ve miktarına dair şu bilgileri sunmaktadır. [Tablo 1]

Tablo 1: 1906 Yılında Çankırı Panayırına Katılan Tüccar ve Mallar

\begin{tabular}{|l|l|l|l|}
\hline $\begin{array}{c}\text { Geldiği } \\
\text { Şehir }\end{array}$ & \multicolumn{1}{|c|}{ Tacir } & \multicolumn{1}{c|}{ Miktar } & \multicolumn{1}{c|}{ Çeşit } \\
\hline \multirow{2}{*}{$\begin{array}{l}\text { M. G. Asdavatzaduryan } \\
\text { Kardeşler }\end{array}$} & 34 Balya & yazma \\
\cline { 3 - 4 } & & 25 balya & kuşak \\
\hline
\end{tabular}

Uludağ Üniversitesi Fen-Edebiyat Fakültesi Sosyal Bilimler Dergisi Uludağ University Faculty of Arts and Sciences Journal of Social Sciences Cilt: 23 Sayı: 42 / Volume: 23 Issue: 42 


\begin{tabular}{|c|c|c|c|}
\hline \multirow{17}{*}{ Tokat } & & 8 balya & yazma \\
\hline & \multirow[t]{2}{*}{ İbranosyan Kardeşler } & 34 Balya & yazma \\
\hline & & 8 balya & kuşak \\
\hline & \multirow[t]{3}{*}{ K. Ölçücüyan ve Oğulları } & 20 balya & yazma \\
\hline & & 8 balya & kuşak \\
\hline & & 8 balya & bez \\
\hline & Parsegyan Kardeşler & 30 balya & yazma \\
\hline & Setenciyan ve Şerikleri & 20 balya & yazma \\
\hline & & 8 balya & kuşak \\
\hline & & 10 balya & bez \\
\hline & Lazariti ve Şerikleri & 20 balya & yazma \\
\hline & $\begin{array}{l}\text { Tarakciyan, Poladyan ve } \\
\text { Buynuzyan }\end{array}$ & $15-20$ balya & $\begin{array}{l}\text { kâğıt içi yazma, } \\
\text { kadınlara } \\
\text { mahsus }\end{array}$ \\
\hline & D. Ferhadyan & 15 balya & yazma \\
\hline & Köylüyan ve Oğulları & 14 balya & yazma \\
\hline & Cilvoğlu İlia & 20 balya & bez \\
\hline & Tirityan Kardeşler & 36 balya & bez \\
\hline & H. Karagözyan & 26 balya & bez \\
\hline Merzifon & $\begin{array}{l}\text { İbranosyan Kardeşler, Kh. } \\
\text { Daldabanyan, H. Keşişyan, } \\
\text { B. Şahbenderyan, Elbekyan } \\
\text { ve diğerleri }\end{array}$ & $500-550$ balya* $^{*}$ & alaca \\
\hline & $\begin{array}{l}\text { S. Mikaelyan ve Cihanyan } \\
\text { Şirketi }\end{array}$ & $50-60$ balya & bakırişi \\
\hline $\begin{array}{l}\text { Sim Hac1 } \\
\text { Köyü }\end{array}$ & $\begin{array}{l}\text { B. Keşişyan ve Tuysüzyan } \\
\text { Kardeşler }\end{array}$ & $80-100$ balya & $\begin{array}{l}\text { havlu, futa, } \\
\text { banyo takımı vs. }\end{array}$ \\
\hline Kastamonu & $\begin{array}{l}\text { Movses Keorkyan, } \\
\text { Cancikyan, Pilavoğlu, } \\
\text { Pavlidis, Hacı Yorgi ve } \\
\text { diğerleri }\end{array}$ & 150 balya & $\begin{array}{l}\text { kuşak, çarşaf, } \\
\text { gömleklik } \\
\text { kumaş, havlu } \\
\text { vb. }\end{array}$ \\
\hline & $\begin{array}{l}\text { İbranosyan Kardeşler } \\
\text { (Kastamonu şubesi) }\end{array}$ & & $\begin{array}{l}\text { manifatura } \\
\text { çeşitleri }\end{array}$ \\
\hline
\end{tabular}

* Elbekyan yukarıda incelenen mektubunda bu sayının 650 balya olduğunu belirtmiştir. Bivrakn, 1906, 25 Kasım: 1039. 


\begin{tabular}{|l|l|l|l|}
\hline Zile & $\begin{array}{l}\text { İbranosyan Kardeşler ve } \\
\text { Bağdasar Harikyan }\end{array}$ & $120-150$ balya & Alaca \\
\cline { 2 - 4 } & Pol Gazel & & Halep işi \\
\hline Kayseri & $\begin{array}{l}\text { Deark Avşaryan, } \\
\text { Tahtaburunyan, Diar } \\
\text { Mamas Camuzyan (aslen } \\
\text { Kayserili, Kastamonu'dan } \\
\text { gelmiş) }\end{array}$ & $70-80$ balya & Yazma \\
\hline Gürün & $\begin{array}{l}\text { Deark Afaryan, Khaçer } \\
\text { Semerciyan, Hovhan } \\
\text { Dedeyan, Avdızade } \\
\text { Mehmet Ef., Nahabed } \\
\text { Keşişyan, Apkar Çokkaryan }\end{array}$ & $80-100$ balya & şal, kuşak \\
\hline Ankara & $\begin{array}{l}\text { Deark Levi Alfons ve Hac1 } \\
\text { Anton }\end{array}$ & & $\begin{array}{l}\text { Halep işi } \\
\text { De Kghemes Uğacyan }\end{array}$ \\
\hline Ankara & $\begin{array}{l}\text { Deark Stephan Manavyan } \\
\text { Diar Bayramyan ve Apas } \\
\text { Ağa }\end{array}$ & & Hazır giyim \\
\hline Kırşehirden & $\begin{array}{l}\text { Boghos Ağa İzmiryan ve } \\
\text { birkaç Türk tüccar }\end{array}$ & Seccade, kilim \\
\hline Sivrihisar & Türk tüccar & $\begin{array}{l}\text { Kimyon, çorap } \\
\text { ve at eğeri için } \\
\text { özel keçe }\end{array}$ \\
\hline Tosya & Yün kuşak \\
\hline
\end{tabular}

Kaynak: Aşıkyan, 1906c: 958-959; Aşıkyan, 1906ç: 993-995.

$\mathrm{Bu}$ tüccar arasında bazılarının yaptıkları satışlara ve satış yollarına dair bilgilerimiz de mevcuttur. Yukarıda Merzifonlu ve Zileli tacirlerin satışlarına dair bilgiler paylaşılmıştı. Onlar dışında Kayserili yazma tüccarına ve mallarına dair de bilgi mevcuttur. Kayserili tüccarların getirdiği mallar arasında $70-80$ balya yazma sadece üç cinsten oluşmaktaydı. Kayseri yazmalarının fiyatları 1905 ile kıyaslandığında epey düşmüş ve piyasa küçülmüştü. Aşıkyan'a göre bunun bir sebebi Tokat yazmasının epey ilerlemiş olmasıydı. Kayseri yazmasının ucuz olmasının en büyük sebebi, Kayseri'de günlük amele ücretlerinin çok düşük olmasıydı ki bu sayede Tokat yazmasıyla ürünleri daha düşük kalitede ve düzensiz olmasına rağmen rekabet edebiliyordu. Tokat 
yazması ise zevkinin inceliği ve kalite bakımından bir standardı olması bakımından Kayseri yazmasından üstündü. Bu yüzden de Kayseri yazması gerilemiş, üretildiği yerde yani Kayseri'de dahi Tokat yazması kullanılır olmuştu. Bu sebeplerden ötürü 1906'daki Çankırı panayırında düşük fiyatlarına rağmen Kayseri yazmalarında büyük satış gerçekleşmemişti. Sadece Camuzyan Efendi getirdiği malların tamamını satabilmişken Avşaryan ve Tahtaburunyan Efendiler Çerkeş panayırına gidip kalan malı orada satmak zorunda kalmışlardı.

Gürün'den gelen şal ve kuşaklara da talep azdı, bu yüzden fiyatlar da yüksek olmadi. Kalan mallar, Ankara, Çerkeş ve diğer pazarlara gönderilmişti. Benzer şekilde Ankara'dan panayıra katılan Deark Stephan Manavyan ve Kghemes Uğacyan da hazır kıyafetlerin ancak yarısını satabilmişler ve kalan malları Çerkeş panayırına göndermişlerdi. Bunun en büyük sebebi ise köylülerin alım gücünün dar olmasıydı. Halep işi mallar satan ve Ankara'dan gelen Deark Levi Alfons ve Hacı Anton ortalama fiyatlarla ve vadeli olarak satış yaparlarken Zile'den gelen Pol Gazel ise Çankırı piyasasına uygun mal getirmediği için çok az mal satabildi.

Kırşehir'den gelen Diar Bayramyan ve Apas Ağa az miktarda seccade ve kilim getirmiş ve yüksek fiyatla satmışlardı. İçeriği bilinmese de Aşıkyan mallarını satarken bin bir ilginç hareketle sattıklarını söylemektedir ki bu bize panayırlarda satış için pazarlama yöntemlerinin geliştirildiğini düşündürür. Önemli bir ham madde olan yün 1906'da çok fiyatlandığı için birçok tüccarın büyük miktarda malla katılmaya gücü yoktu, sadece birkaç tüccar satışta başarılı olabilmişti. Sivrihisar'dan gelen Boghos Ağa İzmiryan, çorap talebi çok olduğu için birkaç balya çorap siparişi daha almış ve onu da tatmin edici fiyata satmayı başarmıştır. Tosya'dan gelen tüccarlar kuşakların büyük kısmını yüksek fiyattan satmış ve ellerinde az mal kalmıştı (Aşıkyan, 1906ç: 994). 
Tacirlerin panayırdaki başarıları, müşterilerin alım gücü ve Çankırı piyasasını bilmek gibi unsurlarla da ilişkiliydi. Müşteri zevkine yönelik mal sunmak, satış yapmanın birincil şartlarından biriydi. 1904 yılında Çankırı panayırında bulunan Merzifonlu tacir M.E. bu perakende satışları yöre halkının gözünden şu şekilde anlatıyordu:

10-15 saat uzaklıktan köylüler de [panayıra] geliyor. Birkaç çift Tokat yazması, birkaç tane Merzifon manusası -burada alaca- diyorlar ve birkaç tane de Kastamonu çarşafiyla köylü kızlarına epey değerli ve güzel bir çeyiz hazırllyorlar. Sahip hizmetçisine, anne kizına, kayınpederi gelinine bir tane alaca hediye allyor. Bütün pazar dolu. Tellallartn bağırışları, kalabalı̆̆ın uğultusu kulağı rahatsız ediyor... Köylüler bütün basitliğin içinde sicak duygularla alaca ve diğer yerel mamullerin dayanıklılığl üzerine konuşuyorlar. Biz ne derece ipek mamullerini seviyorsak onlar da yerel mamulleri seviyorlar (E., 1904: 1).

M.E.'nin sözlerinden panayırda kadınların da alışveriş yaptıkları anlaşılmaktadır. Bunu Aşıkyan da iki cinsiyetten de alıcıların panayırı doldurduklarını söyleyerek teyit eder (Aşıkyan, 1906b: 922).

\section{Amasya Panayırının Sosyal ve Kültürel Yanları}

Çankırı ve Amasya panayırları, ticarî önemlerinin yanında sosyal fonksiyonlara da sahip açık hava buluşma alanlarıydı. Panayırlarda çeşitli eğlence ve spor faaliyetleri düzenlenirdi (Türkoğlu, 2008: 159). Bu açıdan panayırlar, sosyal yaşama büyük bir canlılık katarak kuruldukları şehirlerin kısa süreliğine de olsa sosyal merkezleri konuma gelmekteydiler. 20. yüzyıl başlarında Amasya'da öğretmenlik yapan Soğikyan'ın yazısı bu canlılığı ve panayırdaki sosyal ve eğlence faaliyetlerini ifade etmektedir. Şehre yeni gelmiş olan Soğikyan, okulun bahçesinde öğrencilerin panayırla ilgili heyecanlı konuşmalarını duyar ve panayıra ilgi duymaya başlar. Panayır, şehrin sosyal yaşamında o kadar merkezîdir ki okullar panayır dönemi kapalı olurlar. 15 Ekim'de başlayan panayır sırasında, o yıl her zamankinden farklı olarak okullar kapanmamasına rağmen öğrencilerin yarısı da okula gelmeyip panayıra gitmişlerdir. Panayır cuma günü mutasarrıfın ve diğer erkânın katıldığı

Uludağ Üniversitesi Fen-Edebiyat Fakültesi Sosyal Bilimler Dergisi Uludağ University Faculty of Arts and Sciences Journal of Social Sciences Cilt: 23 Sayı: 42 / Volume: 23 Issue: 42 
büyük bir tören ile açılmış, tören sırasında okul öğrencileri Sultan II. Abdülhamid'in sağllğı için dua etmişlerdir (Erdoğru, 1999: 6-7).

Soğikyan, panayırın ikinci günü insan ve hayvanlardan oluşan büyük bir kalabalıkla beraber şehirden 45 dakika uzaklıktaki panayır yerine ulaşır. Ulaştı̆̆ındaki ilk manzara ilgisini çeker, bir tiyatro oyununa benzettiği manzarada reji kolcusuna rastlayan "bir adam acı içinde düşmüş, son nefesini veriyor gibi"dir (Soğikyan, 1904: 1). Kolcuların genel olarak panayırların güvenliklerinden sorumlu oldukları bilinmektedir (Şen, 1996: 96). Panayırların tütün ticaretinin yoğun olarak yapıldığı ve vergilendirildiği düşündüğünde Amasya panayırında da tütün tacirleri olduğu ve Reji'nin kuruluşundan sonra da panayırlardaki tütün satışı denetimini reji kolcularının üstlendiğini anlaşılmaktadır (Şen, 1996: 93; Kaçan Erdoğan, 2016: 143 vd.).

Gerek Soğikyan gerekse ondan bir sene sonra panayır hakkındaki izlenimlerini yazan Keçeciyan için panayırın birincil önemi ticarî değil sosyaldir. Soğikyan, hayvan pazarından sonra at pazarına giderek oradaki ciddi kalabalıktan bahseder. Kalabalık merakla cirit oyununu beklemektedir. Bir at kümesi, süslenmiş, iki sıra hâlinde düzenlenmiştir. Soğikyan'a göre bunlar çevre köylerden gelmiş Kürtlerdir. Bu manzarayı ve akabindeki oyunu çok etkileyici olarak niteler. Pazar günü ise güreş ve at yarışı ile panayırın eğlencesinin en yoğun yapıldığı gündür.

$\mathrm{Bu}$ eğlencelerin panayırın en merkezî faaliyetleri olduğu düşünülebilir. Hayvan tacirleri hayvanları bırakmış, oyunların etrafında toplanmışlar, pazarlıklar ve satışlar durmuştur. Meydanda değişik cemaatlerin kalabalığı mutasarrıfı çevrelemektedir. İlk önce bir grup pehlivan meydana çıkar, tellal, galipleri sevgi dolu sözler ve ödül vaatleriyle teşvik etmektedir. Pehlivanlar üç gruba bölünürler ve sonra da tek tek karşı karşıya gelirler. Soğikyan'a göre herkesin sempati duyduğu bir pehlivan vardır. Mutasarrıf da galiplere hediyeleri kendi eliyle vermiştir.

Uludağ Üniversitesi Fen-Edebiyat Fakültesi Sosyal Bilimler Dergisi Uludağ University Faculty of Arts and Sciences Journal of Social Sciences

Cilt: 23 Sayı: 42 / Volume: 23 Issue: 42 
Daha sonra kalabalık at yarışı meydanına gider. Çember hâlinde bayraklar dizilmiş, en büyük bayrak valinin önündekidir. İlk olarak yarışa hazırlananlar üçe bölünürler, bayraklarla sınırlandırılmış çemberin içinde 9-8-7 tur atacaklardır. Büyük bayrağa ilk ulaşan hediyeler alacaktır. Tellalların hep birden bağırmaya başlamasıyla yarış başlar. Binicilerin hepsi 16-20 yaşlarında gençlerdir. Kazananlar kuvvetli bir alkıştan sonra atlarından inerler ve mutasarrıf onları da överek hediyelerini verir. Panayırdan çok etkilenen Soğikyan'a göre bu yarışlar antikçağdaki olimpiyatları hatırlatmaktadır (Soğikyan, 1904: 1).

Soğikyan'dan bir yıl sonra Keçeciyan da Amasya panayırına dair anlatısında at yarışlarına odaklanır. Panayır 1905 yılında, 7-11 Ekim tarihlerinde, Cuma-Pazartesi günleri arasında kurulmuştu. Keçeciyan'a göre ticaret dışındaki vakitleri ziyaretçiler eğlence ile geçirmektedirler. İlk iki gün hava yağmurlu olmasına rağmen güreş ve cirit müsabakaları gerçekleşmiştir. Bütün müsabakalar boyunca davul zurna devam ederek yarışmalara katılanlara şevk, izleyicilere de mutluluk vermektedir. İlk at yarış1 pazar günü, ezanî saatle 7'de davulların ritmiyle başlamıştır. Birinci olan Amasyalı bir yerli, ödül olarak bir buzağıyı almış, binlerce kişinin alkışı altında ova inlemiştir. İkinci yarış ise 9'da başlamış, bu yarışı da bir yerli kazanmış ve ödül olarak bir kamçı almıştır (Soğikyan, 1904: 1).

Panayırların dinî törenlerle birleştirildiği ve farklı kültürel özellikler kazandığı da bilinmektedir. Bunların bir örneği Tekfurdağı'nda (Tekirdağ) Ermenilerin panayırıyla ayinlerinin birleştirilmesidir (Şen, 1996: 1). Makalenin ana temasını oluşturan Çankırı ve Amasya panayırlarında dinî öğelerin yerine dair bir bilgimiz yoktur. Bununla beraber sosyal ve kültürel fonksiyonlarına dair bir örnek için eylül ayının başında açılan ve üç gün süren İspir panayırına değinilebilir. Panayır, Hz. İsa'nın gerildiği haçın İran'dan Bizans topraklarına dönüşünün anıldığ 1 Kutsal Haç (Khaçverats) yortusuna denk gelmektedir. 1904 yılında Arevelk gazetesine bölgeden gönderilen bir mektup, panayırın ticareti ve 
dinî-sosyal yanlarının iç içe geçmişliğini ortaya koymaktadır. O yıl yaklaşık yirmi bin kişinin geldiği panayıra, çevre illerden başta Rize, Erzincan, Bayburt ve Erzurum olmak üzere tacirler gelmiştir. Tüccarın her biri yaklaşık 200-300 altınlık mal getirmiş ve yaklaşık olarak 80009000 altınlık bir ticaret gerçekleşmiştir. Muhabire göre en çok katır tüccarı satış yaparken, kitap taciri ise hiç iş yapamamış, getirdiği kitapları geri götürmüştür (Arevelk, 1904, 21 Ekim: 1).

İspir panayırının dinî yanı ise panayırın Surb Hovhan manastırını ziyaret ile başlamasıdır. Burası Ermeniler için eski bir kutsal haç yeridir. Muhabire göre eski bir dinî adet artık ticarî bir faaliyetin etrafında şekillenmektedir (Arevelk, 1904, 21 Ekim: 1).

\section{Sonuç}

19. yüzyılın ikinci yarısından itibaren farklı yörelerde eski panayırların tekrar canlandıkları ve yeni panayırların kuruldukları gözlemlenmiştir. $\mathrm{Bu}$ panayırların bir kısmı da Orta Anadolu ve Kızılırmak havzasındaki şehir ve kasabalarda kurulmaktaydılar. Bunlar arasında Çankırı ve Amasya panayırları ticarî ölçekleri, katılan tüccarın ve malların geldikleri şehirlerin çeşitliliği gibi unsurlarla o bölgenin en önemli panayırları konumundaydılar. Panayırlar, gerek kuruldukları şehrin gerekse tüccarın geldikleri şehrin imalat ve ticarî hayatları için büyük önem arz etmekteydiler, Çankırı panayırında tekstil ürünleri ve Amasya panayırındaki hayvan pazarı şehrin ihtiyaçlarının karşılanması kadar çevre şehirlerdeki imalat sanayileri üzerinde de doğrudan etkiye sahiptir. Ayrıca Amasya panayırının çeşitli spor müsabakalarıyla eğlence yönü kuvvetlidir; dolayısıyla ticarî olduğu kadar sosyal yönleri olan bir organizasyondur.

Panayırlar hakkındaki mevcut çalışmalar, ağırlıklı olarak Rumeli ve Batı Anadolu'daki fuarlara odaklanmakta ve kullandıkları arşiv malzemelerinin doğası gereği panayırlardaki vergiler, güvenlik, imar faaliyetleri gibi merkezî devletin sorumluluk alanına giren konulara 
ağırlık vermektedirler. Panayırlar hakkında dönemin gazete ve dergilerinde yayınlanan tüccar ve katılanların rapor ve gözlemleri ise panayırların aslî unsuru olan tüccarın da panayırlardaki önemine dikkat çekmekte, panayırların ticarî olarak nasıl işlediklerine dair bilgiler sunmaktadır. Bu farklı perspektiflerin ileride arşiv belgeleri ışı̆̆ında yapılacak olan farklı çalışmalara da katkıda bulunacağı düşünülebilir.

\section{Bilgi Notu}

Makale, araştırma ve yayın etiğine uygun olarak hazırlanmıştır. Yapılan bu çalışma etik kurul izni gerektirmemektedir.

\section{Kaynakça}

Arevtragan Kronig: Amasioy Donavacarı [Ticaret Haberleri: Amasya Panayır1]. (1906, 30 Eylül). Bivrakn, 23(36), 858.

Arevturi Geyankı Kavarneru Mej: Amasioy Panayirı [Taşrada Ticaret Hayat1: Amasya Panayır1]. (1906, 25 Kasım). Bivrakn 23(44), 10451047.

Aşıkyan, K. H. (1906a). Çankiri donavacarı Arevduri zarkatsman desagedov [Ticaretin terakkisi bakış açısından Çankırı Panayırı]. Bivrakn, 1(35), 821-826.

Aşıkyan, K. H. (1906b) Çankırii Donavacarı: Marzovantsi Vacaragannerun Voroşumı yev Ziletsinerun Şahı [Çankırı Panayırı: Merzifonlu Tüccarın Kararı ve Zilelerin Kazancı]. Bivrakn, 23(39), 920926.

Aşıkyan, K. H. (1906c). Çankirii Donavacarı [Çankırı Panayırı]. Bivrakn, 23(40), 958-959.

Aşıkyan, K. H. (1906ç). Osm[anyan] Pnik Abrankner: Kayseri YazmanGurini Şalı [Osmanlı Yerli Mamülleri: Kayseri Yazması-Gürün Şalı]. Bivrakn, 23(42), 993-995. 
Aşıkyan, K. H. (1906d). Badaskhan Marzovani Vacaragannerun [Merzifon Tüccarına Cevap]. Bivrakn, 23(49-50), 1192.

Çalışkan, V. (2019). Modern fuarlar ve festivaller arasında giderek kaybolan organizasyonlar: Geleneksel ilçe ve köy panayırları. Millî Folklor, 31(121), 65-80.

Çankırii Donavacarı [Çankırı Panayırı] (1906, Eylül). Bivrakn, 23(34), 793-794.

Dndesagan Nivter: Donavacarnerı [İktisadi Konular: Panayırlar] (1904, 28 Haziran). Arevelk, no. 5592, s. 1.

Doğan, M. (2011). Imparatorluk'tan Cumhuriyet'e panayırlar. (Yayınlanmamış yüksek lisans tezi). Ankara: Hacettepe Üniversitesi Sosyal Bilimler Enstitüsü.

E., M.M. Vicagakragan Noter: Çankırı yev ir donavacarı [İstatisk notları: Çankırı ve Panayırı]. Arevelk, no. 5708, 10 Kasım 1904, s. 1.

Erdoğru, M. A. (1999). Ondokuzuncu yüzyılda Osmanl Imparatorluğunda hafta pazarlarl ve panayırlar. Ege Üniversitesi Edebiyat Fakültesi Yayınları.

Faroqhi, S. (2006). Balkan panayırlarının eski tarihi. (Çev: E. S. Özcan), Osmanlı Şehirleri ve Kırsal Hayatı içinde (157-186. ss.). Doğu Batı.

Girgeç, N. (2008). Zile panayır üzerine halkbilimsel bir inceleme. (Yayınlanmamış yüksek lisans tezi). Ankara: Gazi Üniversitesi Sosyal Bilimler Enstitüsü.

Kaçan Erdoğan, M. (2016). Balkanlarda uluslararası bir organizasyon: İslimye panayırı. Belleten, 80(287), 123-155.

Kapamaciyan, S. (1909). Kamer: Pokrig Cambordl Arevelki Mej [Kamer: Küçük Seyyah Doğu'da]. Sakayan. 
Karaca, M. (2017). Türkiye'de panayır kültürü ve Çankırı panayırları. (Yayınlanmamış doktora tezi). Ankara: Hacettepe Üniversitesi Sosyal Bilimler Enstitüsü.

Kavari Gyanken: Zhoghovrtagan Sovorutyunner [Taşra hayatından: Halk Gelenekleri]. (1904, 21 Ekim). Arevelk, no. 5691, s. 1.

Keçeciyan, M. Donavacarn u Tsiarşavı Amasioy Mej [Amasya'da Panayır ve At Yarışları]. (1905, 2 Kasım). Arevelk, no. 6009, s. 1.

Kilinçoglu, D. T. (2015). Economics and capitalism in the Ottoman Empire. Routledge.

Kostandyan, E. (2003). Konstantinupolsi 'Arevelk' Oratertı [Konstantinopolis'in Arevelk Gazetesi]. HHGAA Gitutyun Hratarakçutyun.

Küpeli, Ö. (1999). Osmanlı Devleti'de panayır organizasyonları ve Gönen Hacı İsa Panayırı'nın tarihine dair. G. Eren, K. Çiçek, C. Oğuz (Ed.), Osmanlı içinde (490-497. ss.), 3, Yeni Türkiye Yayınları.

Marzovantsi Vacaragannerun Badaskhanı [Merzifonlu Tüccarın Cevabı] (1906, 25 Kasım). Bivrakn, 23(44), 1039-1041.

Nor Panayir [Yeni Panayır]. (1907, 3 Şubat). Bivrakn, 24(11-12), 277.

Özcan, K. (2006). Anadolu'da Selçuklu Dönemi yerleşme tipolojileri-IPazar ya da panayır yerleşmeler. Anadolu Üniversitesi Sosyal Bilimler Dergisi, 6(1), 205-223.

Özcan, T. (2007). Pazar (Osmanlı Dönemi). Türkiye Diyanet Vakfi İslam Ansiklopedisi içinde (206-208. ss.), 34, Türkiye Diyanet Vakfi.

Özger, Y. (2018). Osmanlı'dan Cumhuriyet'e Yozgat yöresinde kurulan haftalık pazarlar ve panayırlar. International Journal of Humanities and Education, 4(9), 103-121. 
Pakalın, M. Z. (1993). Okka. Osmanlı Tarih Deyimleri ve Terimleri Sözlüğü içinde (723. ss.), II, Milli Eğitim Bakanlığı Yayınları.

Soğikyan, M. Amasioy Donavacarı [Amasya Panayırı]. (1904, 25 Kasim). Arevelk no. 5721, s. 1.

Şahin, İ. (2013). Yiğitbaşı. Türkiye Diyanet Vakfi İslam Ansiklopedisi içinde (549-550. ss.), 43, Türkiye Diyanet Vakfi.

Şahin, M. (2013). İlk ve Ortaçağlarda Zile. History Studies, 5(3), 207222.

Şen, Ö. (1996). Osmanlı panayırları (18.-19. yüzyıl). Eren.

Türkoğlu, Ö. (2008). Tarihi Yapraklı panayırı hakkında bazı notlar. Çankırı Araştırmaları Dergisi, (3), 157-160. 


\section{EXTENDED ABSTRACT}

Annual fairs played significant economic and social roles in the Ottoman world. Although some fairs lost their former size and importance, many new fairs were established from the second half of the nineteenth century onward. The scholarship has mainly focused on the fairs in the Balkans which were of greater size and international significance than those in Anatolia. However, there were a series of fairs in Central Anatolia and the Kuzllırmak basin, and the fairs in Çankirl and Amasya were among the most important yet understudied ones among them. The scholarship heavily uses state archives and therefore reflect the concerns and priorities of the Ottoman central administration. The available studies concentrate on certain aspects of the fairs such as organization of the fairs by the central authorities, customs and other taxes extracted from goods, rents of the fairs sites and security of the fairs.

Armenian language press of Istanbul, particularly the daily Arevelk newspaper and the commercial magazine Bivrakn showed special interests in the Çankirl and Amasya fairs. The reports and observations by the merchants and other participants in the fairs provide details about their economic activities and social functions. The fairs hosted a significant number of merchants, particularly textile merchants who came from different towns in the broader region. The reports and observations underline substantial commercial activities in the fairs as well as in the towns where goods were produced. For instance, the Çankirl fair had an impact on the markets in Tokat and Merzifon as the fair served as the main outlet for the producers and merchants in those towns. Likewise, the observations and the reports show that the Çankirl fair was the main market for textile goods in the region which attracted buyers from a wider geography. On the other hand, Amasya fair served both as the main animal market and essential for the needs of the city. Moreover, the fair also provided hide which was used in the leather industry in the surrounding regions. The reports also show that competition between local shop keepers and merchants and between merchants of different towns were quite common in the fairs. The reports also discuss various sale strategies and different external and internal factors in the success and failure of the merchants in the fairs. Among the reasons were general contraction of the market, lack of cash, and wrong sale policies including failure to comprehend the needs and taste of the local population. In addition to the commercial aspects, the fairs also had social functions particularly sport games, which included wrestling competitions, cirit game, and horse races. These brought a large number of visitors together in the fairs, and aimed to bolster the commerce at the fairs.

This study of the Çankirl and Amasya annual fairs based on newspapers and periodicals show the lively commercial and the social life from the perspective of the 
merchants and visitors. Therefore, it highlights the vibrant economic and social world of annual fairs and their importance for the communities in Anatolia in the early twentieth century. 